\title{
IMPROVING STUDENT ACTIVITIES AND LEARNING OUTCOMES THROUGH RECIPROCAL TEACHING STRATEGIES WITH AUDIOVISUAL MEDIA
}

\author{
Binti Munawaroh ${ }^{1 *}$ \\ ${ }^{1}$ SMAN 3 Bondowoso, Indonesia \\ *E-mail: bmunawaroh05@gmail.com
}

\begin{abstract}
The research is about classroom action research in class XI MIPA 2 SMA Negeri 3 Bondowoso in the 2019/2020 school year. Data collection methods in this research are observation, documentation, and tests. The data obtained are student interest in learning, teacher activities and student learning activities during the learning process and learning outcomes in cycle I and cycle II. Student learning activity data obtained from observations. Student learning activities were analyzed descriptively. While the completeness of students' mathematics learning outcomes was obtained from the postest results. Classical student learning activities have increased in each activity indicator observed from cycle I to cycle II. This can be seen from students who do activity indicators, the percentage increases from cycle I and cycle II, from $73 \%$ to $93 \%$. The increase in completeness of student learning outcomes occurred in each cycle, namely $31.5 \%$ in cycle I to $89.6 \%$ in cycle II. Based on the results above, it shows that the Reciprocal Teaching Strategy with Audiovisual Media can be used as an alternative to learning that can make students more active and can understand mathematical concepts in order to improve learning activities and student learning outcomes.
\end{abstract}

Keyword: Reciprocal Teaching Strategy, Audiovisual Media

\section{INTRODUCTION}

The main problem in learning in formal education today is the low absorption of students. This can be seen from the average student learning outcomes which are still concerning. This achievement is the result of learning conditions that are still conventional and do not touch the realm of the dimensions of the students themselves, namely how to actually learn [6]. To improve student achievement, it can be done by improving the quality of learning in schools. demands a paradigm shift in education and learning, especially at the formal education level. The paradigm shift is the learning orientation from being teacher-centered to being student-centered [8]. This is the reason why their Mathematics learning achievement is still below the MCC (Minimum Criteria Completeness). Lack of interest from students is the main cause of their low achievement. It is necessary for a teacher to foster interest from students so that they are enthusiastic and even like Mathematics.

Fostering students interest and improving education quality, it is necessary to improve so that the learning objectives can be achieved. Therefore, Mathematics teachers should implement learning strategies that provide opportunities for students to actively participate in Teaching and Learning Activities (TLA). According to Trianto [6], reverse teaching (reciprocal teaching) is a constructivist-oriented learning strategy that has the benefit of achieving learning objectives through student-centered learning activities so that students can improve their critical thinking skills and be able to explain their findings

\footnotetext{
${ }^{1}$ Teacher of SMAN 3 Bondowoso.
} 
to students. Others. In this strategy there are four basic strategies, namely formulating questions, predicting answers, clarifying answers, and making summaries [9].

Besides, there are also learning media used to achieve learning objectives. One of the media used in this research is audiovisual media. According to Hamdani [4] audiovisual media is media that contains sound elements and also has visible image elements. To make this happen, the teacher should optimize all of the students' senses to actively listen, write, observe and so on, because each student has a different learning style. There are several types of learning styles, namely audio, visual, audio visual and kinesthetic. In previous research, Herlina [7] found that the use of reciprocal strategy could be beneficial for the students when taking comprehension tests such as National Examination later because the indicators of comprehension used in this study were based on students' graduate competence. Based on that result, we knew that this reciprocal strategy had beneficial for students. Then we try to find that when we use this strategy with audiovisual media in teaching and learning Mathematics. Thus, this study aims to improve the mathematics teaching and learning process by using Classroom Action Research in increasing learning activities and student learning outcomes.

\section{RESEARCH METHOD}

This research was conducted using the classroom action research method which consists of 2 cycles. In the first cycle consisting of one face-to-face and the second cycle consisting of one face-to-face meeting.

1) Data Collection Instruments and Methods

The data collected in this study consisted of student activity, student learning outcomes, and interviews. Types of data, methods and instruments used to collect data in this study

2) Data Analysis

The data analysis used is descriptive analysis which consists of: Data analysis is the process of compiling and processing the data required in research, so that it will produce a justifiable conclusion. This research data analysis method is descriptive qualitative analysis. The data to be analyzed in this study are:

a. Studying student activities during the teaching and learning process using the Reciprocal Teaching Strategy with Audiovisual Media, the percentage of student activeness $\left(P_{a}\right)$ is used with the following formula:

where

$$
P_{a}=\frac{A}{N} \times 100 \%
$$

$P_{a}$ : percentage of student learning activities

$A$ : the number of scores of learning activities obtained by students

$N$ : the maximum score of student learning activities

With the activity criteria as in Table 1 [2] the following:

Table 1. Student Activity Criteria

\begin{tabular}{cc}
\hline Percentage of Activity & Criteria \\
\hline$P_{a} \geq 80 \%$ & Very Active \\
$60 \% \leq P_{a}<80 \%$ & Active \\
$40 \% \leq P_{a}<60 \%$ & Medium \\
$20 \% \leq P_{a}<40 \%$ & Less Active \\
$P_{a}<20 \%$ & Very Less Active \\
\hline
\end{tabular}


b. Calculating the completeness of students' mathematics learning outcomes after learning using the Reciprocal Teaching Strategy with Audiovisual Media, it can be done with the formula [3]:

$$
P=\frac{n}{N} \times 100 \%
$$

$P$ : percentage of student learning outcomes completeness

$n$ : the number of students who have finished studying

$N$ : the number of all students

A student is said to be complete if he has reached a score of $\geq 75$ from a maximum value of 100 . A class is declared complete if there are at least $85 \%$ of students in the class who have achieved individual completeness with a value of $\geq 75$.

3) Teacher Activity Data

Teacher activity data uses the criteria for the level of teacher activity during learning according to Aqib [1].

Table 2. Teacher Activity Criteria

\begin{tabular}{cc}
\hline Score & $\begin{array}{c}\text { Assessment } \\
\text { Category }\end{array}$ \\
\hline 1 & Very less \\
2 & Less \\
3 & Medium \\
4 & Good \\
5 & Very good \\
\hline
\end{tabular}

Analysis of teacher activity data is analyzed by using percentages, with the formula [5]:

$P=$ Precentage

$$
P=\frac{F}{N} \times 100 \%
$$

$F=$ Teacher activity frequency

$N=$ The number of teacher acivity

\section{RESULTS AND DISCUSSION}

Classroom action research was carried out at SMA Negeri 3 Bondowoso in class XI MIPA 2 students in the odd semester of the 2019/2020 school year, with 32 students. This research was conducted in two cycles. Each cycle consists of four stages, namely: planning, implementing, observing or observing, and reflecting. Research data obtained from observation, interviews, and post-test results.

\section{A. Results}

In this study, there were two research cycles in which before starting cycle I, the researcher first carried out pre-cycle learning activities. The following are the results of observations of pre-cycle learning activities whose implementation is still using the lesson plan by the teacher in class XI MIPA 2 SMAN 3 Bondowoso. The data from the observations in this study were in the form of student activities during learning activities.

1) Student Learning Activities

The results of observations of student learning activities in the pre-cycle obtained a summary of student learning activities during class learning as in the Table 3. 
Table 3. Teacher Activity Criteria

\begin{tabular}{clc}
\hline Number & \multicolumn{1}{c}{ Indicator } & $\begin{array}{c}\text { Percentage } \\
\text { of Activity }\end{array}$ \\
\hline 1 & Pay attention to the teacher's explanation & $57,26 \%$ \\
2 & Asking question & $28,21 \%$ \\
3 & Writting / take notes & $59,83 \%$ \\
& Average percentage of student activity & $48,43 \%$ \\
\hline
\end{tabular}

Based on Table 3, the percentage of students' learning activities on average is $48.43 \%$ which means the learning activities of class XI MIPA 2 SMA Negeri 3 Bondowoso before using the Reciprocal Teaching Strategy with Audiovisual Media.

2) Completeness of Student Learning Outcomes

The data on the completeness of student learning outcomes in the pre-cycle obtained a summary of the completeness of student learning outcomes during class learning in Table 4.

Table 4. The percentage of students' mathematics learning outcomes completeness in pre-cycle

\begin{tabular}{cccc}
\hline Cycle & $\begin{array}{c}\text { The number of students } \\
\text { who completed }\end{array}$ & $\begin{array}{c}\text { The number of } \\
\text { students who not } \\
\text { completed }\end{array}$ & $\begin{array}{c}\text { The } \\
\text { number of } \\
\text { students }\end{array}$ \\
\hline $\begin{array}{c}\text { Pre-cycle } \\
\text { Percentage }\end{array}$ & 10 & 22 & 32 \\
\hline
\end{tabular}

Table 4 illustrates that there are 10 students $(31.5 \%)$ who have completed learning from a total of 32 students and the rest are not yet complete, meaning that the percentage of student learning outcomes has not met the classical mastery criteria of $75 \%$.

Based on the results of the pre-cycle analysis, it is necessary to plan for improvement in the form of observations in cycle I learning activities which are used to increase learning activities and students' learning outcomes is a Reciprocal Teaching strategy with Audiovisual Media of Transformation Transformation and Rotation material. The research was carried out by preparing the making of learning tools, then continued by carrying out the first cycle of learning for $4 \times 45$ minutes with translational transformation material.

In cycle 1, learning is carried out in accordance with the learning scenario that has been designed about translational transformation. The teacher divides the students into small groups each consisting of 8 groups of 4 students per group. The teacher distributes student worksheet 1 to students. The process takes about 15 minutes. Before proceeding to the main material, the teacher explains to students about the student worksheet 1 that has been distributed. Furthermore, the teacher explains about translational transformation using PowerPoint presentation slides.

After students have finished making observations, students are asked to write their observations on a sheet of paper and answer all the questions in the student worksheet 1 . The presentation applies the Reciprocal Teaching Strategy with Audiovisual Media. Each group gets the opportunity to make their own contribution. another group asks the results of the description of the material. After completing one group, the next group that presents and the others can propose the views and thoughts of other members. The activity ended with giving awards to the groups based on the results they got on the pre-test and quizes. 
1. Results of Cycle I Data Analysis

Finding out the increase in student interest in learning mathematics, the researcher distributed a questionnaire before class action was carried out in cycle I which can be seen in Table 5 .

Table 5. Student Interest in Learning Mathematics Before Classroom Action

\begin{tabular}{ccc}
\hline Impressions on & $\begin{array}{c}\text { The number of } \\
\text { students }\end{array}$ & Percentage \\
Mathematics Lessons & 2 & $6 \%$ \\
\hline Interesting & 28 & $86 \%$ \\
Usual & 2 & $6 \%$ \\
Not Interesting & 32 & $100 \%$ \\
Total & & \\
\hline
\end{tabular}

Although the majority of students considered mathematics to be mediocre, the reasons conveyed were the same as students who considered mathematics lessons unattractive, namely that mathematics was a lot of memorizing, counting and the teacher's teaching methods were less attractive. Likewise, the neutral (ordinary) choice in the questionnaire tends to be considered a "safe zone" for not choosing an "not interesting" answer option but certainly not an "interesting" answer choice. Therefore, researchers tend to conclude that the choice that the impression of a mathematics subject is "usual" is interpreted as "not interesting". While the reasons given by students why mathematics students are not attractive or mediocre are as follows

Table 6. The reason maths isn't interesting

\begin{tabular}{ccc}
\hline Reason & $\begin{array}{c}\text { The number of } \\
\text { students }\end{array}$ & Percentage \\
\hline Many Figures & 5 & $15 \%$ \\
Counts a lot & 12 & $36 \%$ \\
Learning method is not & 15 & $49 \%$ \\
interesting & 32 & $100 \%$ \\
Total & & \\
\hline
\end{tabular}

Meanwhile, what students expect to make mathematics learning interesting is a variety of learning methods and media. The activities of the first cycle students can be described in Table 7 below.

Table 7. Student Activity Cycle I

\begin{tabular}{clll}
\hline \multirow{2}{*}{ Number } & \multicolumn{1}{c}{ Statement } & \multicolumn{2}{c}{ Score } \\
\cline { 2 - 4 } 1 & $\begin{array}{l}\text { The seriousness of students during the } \\
\text { teaching and learning activities }\end{array}$ & $\times$ \\
2 & $\begin{array}{l}\text { The courage of students to express ideas } \\
\text { verbally }\end{array}$ & $\times$ \\
3 & $\begin{array}{l}\text { The courage of students expressing ideas } \\
\text { in writing }\end{array}$ & & \\
4 & $\begin{array}{l}\text { The courage of students asking questions } \\
\text { Students' ability to complete assignments } \\
5\end{array}$ & $\times$ \\
6 & $\begin{array}{l}\text { on time } \\
\text { The ability of students to respond to } \\
\text { friends' ideas } \\
\text { Cooperation / student interaction in } \\
\text { groups }\end{array}$ & $\times$ & \\
& & &
\end{tabular}




\begin{tabular}{|c|c|c|c|}
\hline \multirow{2}{*}{ Number } & \multirow[t]{2}{*}{ Statement } & \multicolumn{2}{|r|}{ Score } \\
\hline & & 1 & 2 \\
\hline 8 & Students' courage to answer questions & & $x$ \\
\hline 9 & $\begin{array}{l}\text { Student activeness in discussions and } \\
\text { presentations }\end{array}$ & & $x$ \\
\hline 10 & $\begin{array}{l}\text { Student interest in the teaching and } \\
\text { learning process }\end{array}$ & & $x$ \\
\hline
\end{tabular}

Based on the table above, it can be seen that student activity in Cycle I is still lacking where the average percentage of student activity is $73 \%$. Overall, the observation aspects, the highest score obtained in cycle I was 3 and the lowest was 1.

Based on the results of observations during the Teaching and Learning Activities (KBM), the teacher's activities in carrying out the RPP steps in cycle I are as follows:

Table 8. Teacher Activity Cycle I

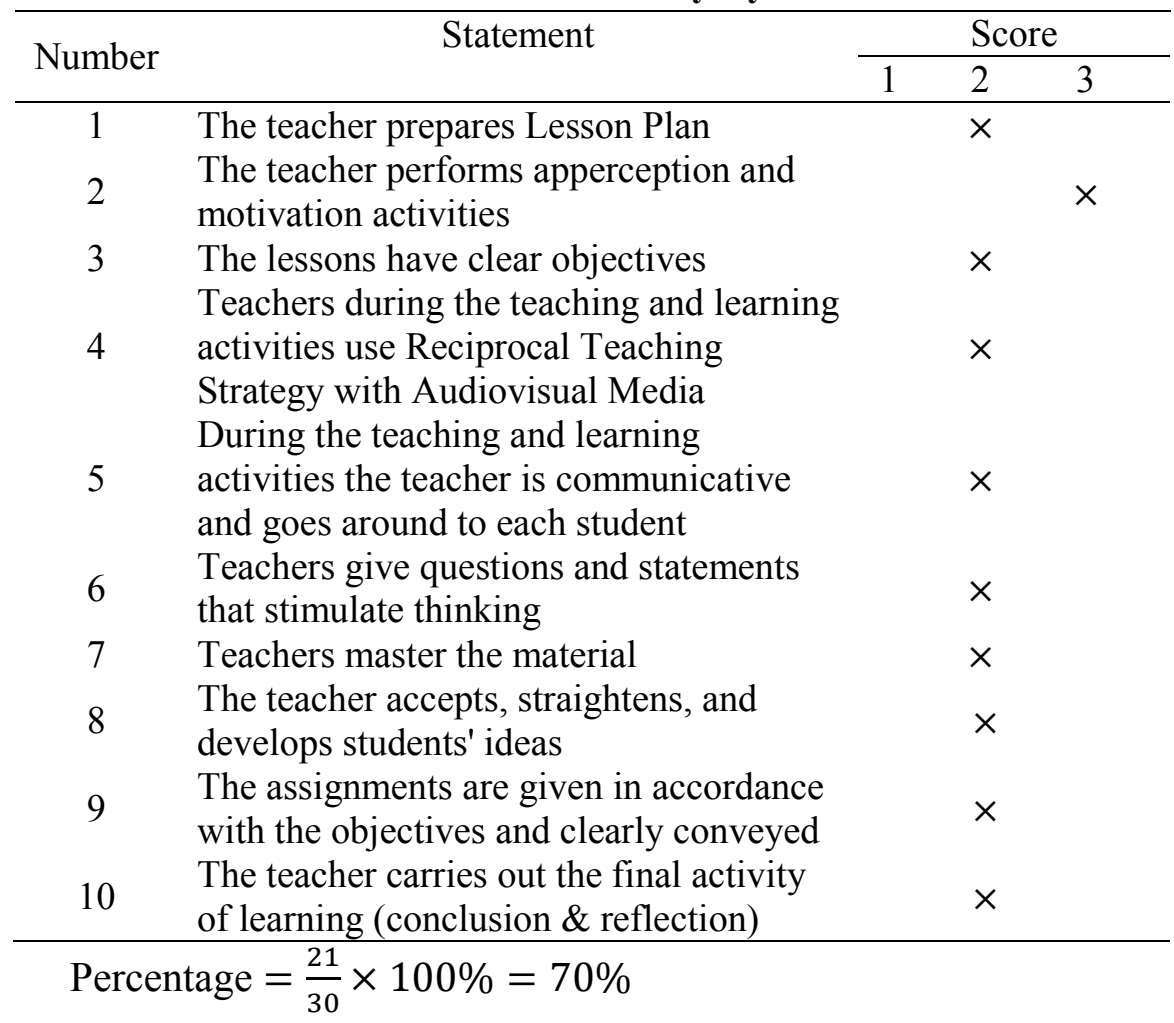

Based on pecentage above, teacher activity in cycle I is still lacking, as shown in the table above, where the average percentage of teacher activity is $70 \%$.

Furthermore, student learning outcomes can be seen in the following table:

Table 9. Student Learning Outcomes Cycle I

\begin{tabular}{clcc}
\hline \multirow{2}{*}{ Number } & \multirow{2}{*}{ Completeness } & \multicolumn{2}{c}{ KKM 75 } \\
\cline { 3 - 4 } & & Total & Percentage \\
\hline 1 & Complete & 12 & 37,5 \\
2 & Not Complete & 20 & 62,5 \\
& & 32 & 100
\end{tabular}

Based on the research, the final results of student learning or completeness in the first cycle were 12 students $(37.5 \%)$ of the 32 students in total were declared 
complete and 20 students (62.5\%) declared incomplete, with a class average score of 67.

Based on the results of observations in cycle I, researchers and collaborators conduct discussions and make action plans for cycle II. In cycle I, even though the students were enthusiastic, researchers and collaborators observed that students had not made Reciprocal Teaching Strategy with Audiovisual Media an important point besides the material being studied. The teacher presented translational transformation material with attractive image media through audiovisual shows in the form of power points and videos. Students began to be enthusiastic in asking questions and discussing, but the activeness of students in discussions and presentations had not run optimally.

At this stage the researcher and collaborator agree to improve the learning scenario. In the action plan for cycle 2 , it needs an adequate introduction from the teacher about the reasons for choosing a learning method and audiovisual media and its relevance to the material. In addition, it is necessary to strengthen the understanding of the concept of the material prior to discussion and presentation.

2. Results of Cycle II Data Analysis

By using the same method, it was obtained cycle II student activity at the first and second meetings in the following table.

Table 10. Student Activity Cycle II

\begin{tabular}{|c|c|c|c|c|}
\hline \multirow{2}{*}{ Number } & \multirow[t]{2}{*}{ Statement } & \multicolumn{3}{|c|}{ Score } \\
\hline & & 1 & 2 & 3 \\
\hline 1 & $\begin{array}{l}\text { The seriousness of students during the } \\
\text { teaching and learning activities }\end{array}$ & & & $x$ \\
\hline 2 & $\begin{array}{l}\text { The courage of students to express ideas } \\
\text { verbally }\end{array}$ & & & $x$ \\
\hline 3 & $\begin{array}{l}\text { The courage of students expressing ideas } \\
\text { in writing }\end{array}$ & & & $x$ \\
\hline 4 & The courage of students asking questions & & $x$ & \\
\hline 5 & $\begin{array}{l}\text { Students' ability to complete assignments } \\
\text { on time }\end{array}$ & & & $x$ \\
\hline 6 & $\begin{array}{l}\text { The ability of students to respond to } \\
\text { friends' ideas }\end{array}$ & & $x$ & \\
\hline 7 & $\begin{array}{l}\text { Cooperation / student interaction in } \\
\text { groups }\end{array}$ & & & $x$ \\
\hline 8 & Students' courage to answer questions & & & $x$ \\
\hline 9 & $\begin{array}{l}\text { Student activeness in discussions and } \\
\text { presentations }\end{array}$ & & & $x$ \\
\hline 10 & $\begin{array}{l}\text { Student interest in the teaching and } \\
\text { learning process }\end{array}$ & & & $x$ \\
\hline
\end{tabular}

Based on the table above, it can be seen that student activity in Cycle II was very good where the average percentage of student activity was $93 \%$.

Furthermore, based on the results of observations during Teaching and Learning Activities (KBM), the activities of the teacher in carrying out the RPP steps in cycle II are as follows: 
Table 11. Student Activity Cycle II

\begin{tabular}{|c|c|c|c|c|}
\hline \multirow{2}{*}{ Number } & \multirow[t]{2}{*}{ Statement } & \multicolumn{3}{|c|}{ Score } \\
\hline & & 1 & 2 & 3 \\
\hline 1 & The teacher prepares Lesson Plan & & & $x$ \\
\hline 2 & $\begin{array}{l}\text { The teacher performs apperception and } \\
\text { motivation activities }\end{array}$ & & & $x$ \\
\hline 3 & The lessons have clear objectives & & & $x$ \\
\hline 4 & $\begin{array}{l}\text { Teachers during the teaching and learning } \\
\text { activities use Reciprocal Teaching } \\
\text { Strategy with Audiovisual Media }\end{array}$ & & & $x$ \\
\hline 5 & $\begin{array}{l}\text { During the teaching and learning } \\
\text { activities the teacher is communicative } \\
\text { and goes around to each student }\end{array}$ & & $x$ & \\
\hline 6 & $\begin{array}{l}\text { Teachers give questions and statements } \\
\text { that stimulate thinking }\end{array}$ & & & $x$ \\
\hline 7 & Teachers master the material & & & $x$ \\
\hline 8 & $\begin{array}{l}\text { The teacher accepts, straightens, and } \\
\text { develops students' ideas }\end{array}$ & & & $x$ \\
\hline 9 & $\begin{array}{l}\text { The assignments are given in accordance } \\
\text { with the objectives and clearly conveyed }\end{array}$ & & & $x$ \\
\hline 10 & $\begin{array}{l}\text { The teacher carries out the final activity } \\
\text { of learning (conclusion \& reflection) }\end{array}$ & & $x$ & \\
\hline
\end{tabular}

$$
\text { Percentage }=\frac{28}{30} \times 100 \%=93 \%
$$

The teacher's activity cycle II is very good as seen in the table above, where the average percentage of teacher activity is $93 \%$. Furthermore, student learning outcomes can be seen in the following table:

Table 12. Student Learning Outcomes Cycle II

\begin{tabular}{clcc}
\hline \multirow{2}{*}{ Number } & \multirow{2}{*}{ Completeness } & \multicolumn{2}{c}{ KKM 75 } \\
\cline { 3 - 4 } & & Total & Percentage \\
\hline 1 & Complete & 28 & 89,6 \\
2 & Not Complete & 4 & 10,4 \\
& & 32 & 100 \\
\hline
\end{tabular}

Based on the research, the final results of student learning or completeness in cycle II were 28 students $(89.6 \%)$ of the 32 students in total were declared complete and 4 students $(10.4 \%)$ were declared incomplete, with a class average score of 85 .

Reflection for the second cycle of action, at the first meeting it could be stated that students were able to link the material through Reciprocal Teaching Strategies with Audiovisual Media. Students have also begun to pay attention to the teacher's explanation in using audiovisual learning media as material for reflection and as a learning medium. At the second meeting, the students' interest in knowing the varied audiovisual learning media was prominent. This seems to be able to inspire or provide new knowledge for students about how rotation transformations are shown clearly in prezy and learning videos via LCD. Universal student activities run optimally

\section{B. Discussion}

Based on the action cycle carried out in cycle I and cycle II, the researcher and collaborator concluded that the objective of action research was successful. Based on the 
results of the questionnaire distributed at the end of the second cycle session, there was an increase in student interest in mathematics. The majority of students expressed interest and motivation to learn mathematics. The complete results can be seen in the following table.

Table 13. Student Interest and Motivation to Learn Mathematics after Action

\begin{tabular}{lcccc}
\hline \multicolumn{1}{c}{ Question } & \multicolumn{2}{c}{ Yes } & No \\
\cline { 2 - 5 } & Total & Percentage & Total & Percentage \\
\hline $\begin{array}{l}\text { Are you interested in learning mathematics, after } \\
\text { using Reciprocal Teaching Strategies and }\end{array}$ & 31 & $97 \%$ & 1 & $3 \%$ \\
$\begin{array}{l}\text { Audiovisual Media? } \\
\begin{array}{l}\text { Does the Reciprocal Teaching Strategy and } \\
\text { Audiovisual Media used in mathematics learning } \\
\text { motivate you to learn mathematics? }\end{array}\end{array}$ & 30 & $86 \%$ & 2 & $14 \%$ \\
\hline
\end{tabular}

Likewise, there was an increase in student responses to mathematics from previously being uninteresting and mediocre to being an interesting subject. Comparison of student responses to mathematics before and after the action as follows.

Table 14. Student Responses to Mathematics Lessons Before and After Action

\begin{tabular}{ccccc}
\hline \multirow{2}{*}{ Student Response to Mathematics Lessons } & \multicolumn{2}{c}{ Before } & \multicolumn{2}{c}{ After } \\
\cline { 2 - 5 } & Total & Percentage & Total & Percentage \\
\hline Interesting & 2 & $6 \%$ & 22 & $63 \%$ \\
Usual & 27 & $80 \%$ & 9 & $34 \%$ \\
Not Interesting & 3 & $14 \%$ & 1 & $3 \%$ \\
Total & 32 & $100 \%$ & 32 & $100 \%$ \\
\hline
\end{tabular}

Whereas in terms of the relationship between the use of audiovisual media as a teaching medium and mastery of the material, the majority of students stated that this method made it easier to understand the material. The following table describes the response to the relationship between understanding the material and learning methods and media.

Table 15. Understanding Student Material Using Reciprocal Teaching Strategies and Audiovisual Media

\begin{tabular}{ccc}
\hline $\begin{array}{c}\text { Understanding Student Material Using Reciprocal Teaching } \\
\text { Strategies and Audiovisual Media }\end{array}$ & Total & Percentage \\
& & \\
\hline Easy & 18 & $54 \%$ \\
Usual & 13 & $43 \%$ \\
Hard & 1 & $3 \%$ \\
Total & 32 & $100 \%$ \\
\hline
\end{tabular}

From the table, the number of students who think that the use of audiovisual media as a teaching medium makes it easier to understand the material is almost the same as the number of students who stated that they were ordinary. There was even a student who stated that this method made him unable to understand the material. This, according to 
the researcher, must be observed and followed up because the cognitive goal of all learning is material understanding.

Based on the results of observations in pre-cycle to cycle II, learning outcomes have increased and also activities for both teachers and students in teaching and learning activities and achieving completeness. The learning outcomes in the pre-cycle were $31.5 \%$. The test results in the first cycle with a grade point average of $37.5 \%$ and the class average score of $89.6 \%$ with an average grade of 85 . Then it can be seen that the students' scores have reached the completeness standard classically at cycle II, namely $\geq 85 \%$. Thus it can be concluded that there is an increase in student learning outcomes in class XI MIPA 2 SMA Negeri 3 Bondowoso on the material of translation and rotation transformation. The graph of the increase in student learning outcomes from pre-cycle to cycle II can be seen in the following figure.

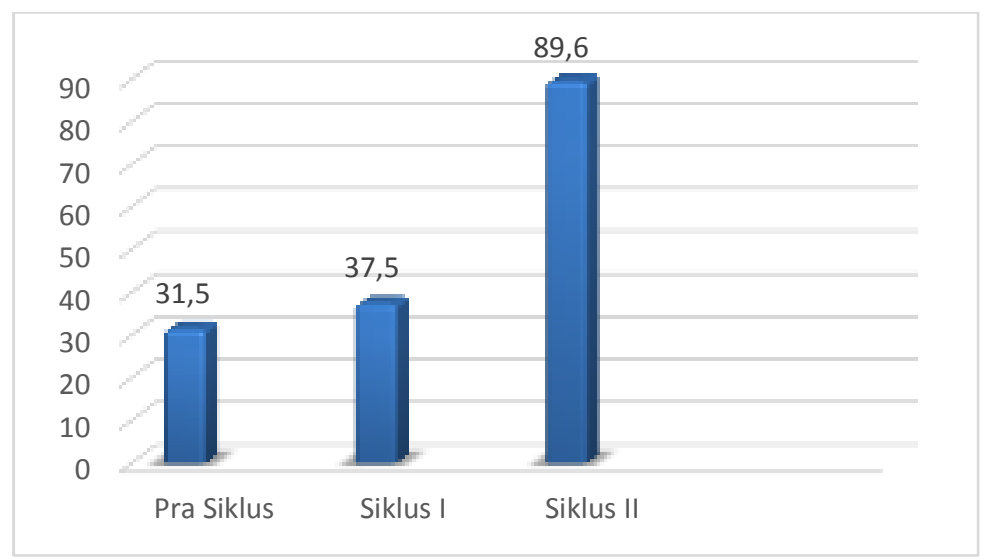

Figure 1. Student Learning Outcomes Diagram

Student activities in pre-cycle activities are still far from expected. Student activity in cycle I was still in the moderate category with a percentage of $75 \%$ and teacher activity in the learning process in cycle I was good enough in terms of delivering material, organizing students and managing the class with a percentage of $70 \%$. In the second cycle the student activity increased with the very good category in terms of asking questions, appearing to the front of the class, cooperating, conditioning themselves in groups, and also giving responses to the results of their friends' presentations with a percentage of $83 \%$. This is because students are familiar with the application of the Reciprocal Teaching Strategy and audiovisual media in the form of power points and instructional videos. Teacher activity also increased in cycle I and cycle II in terms of applying the use of teaching aids with the percentage of scores in cycle I was $70 \%$ with enough categories to be $93 \%$ in cycle II with good categories.

From the results of this research, it was found that success in learning Reciprocal Teaching Strategies with Audiovisual Media can increase student learning activities. This can be seen in cycle I student activity is only $70 \%$ and there is a significant increase in cycle II, namely $93 \%$. Besides, the previous research about the use of reciprocal strategy could be beneficial for the students when taking comprehension tests such as National Examination later because the indicators of comprehension used in this study were based on students' graduate competence [7]. Based on that, the Reciprocal Teaching Strategy with Audiovisual Media at SMA Negeri 3 Bondowoso not only can increase interest, learning activities and completeness of the students' learning outcomes but also can beneficial for the students when taking National Examination. 


\section{CONCLUSION}

From the results of classroom action research which aims to determine the effectiveness of using audiovisual media in an effort to increase students' interest in learning mathematics, we can conclude that using reciprocal teaching strategies with audiovisual media to increase students' interest from and improve learning outcomes in learning mathematics can be said to be successful. Besides, student activities has increase first cycle with a percentage of $75 \%$ and in the second cycle the student activity increased with the very good category in terms of asking questions, appearing in front of the class, collaborating, conditioning themselves in groups, and also giving responses to the results of their friends' presentations with a percentage of $83 \%$.

\section{REFERENCE}

[1] Aqib, Z. (2006). Penelitian Tindakan Kelas. [Classroom action research]. Bandung: Yrama Widya.

[2] Basir, Abdul. (1988). Evaluasi Pendidikan. [Education evaluation]. Surabaya : Airlangga University Press.

[3] Depdiknas. (2004). Kurikulum Sekolah Menengah Kejuruan (2004 Ed.). [Vocational high school curriculum]. Jakarta : Pusat Kurikulum Balitbang Depdiknas

[4] Hamdani. (2011). Strategi Belajar Mengajar. [Teaching and Learning Strategies]. Bandung: Pustaka Setia

[5] Sukiman. (2012). Pengembangan Media Pembelajaran. [Learning Media Development]. Yogyakarta: Pustaka Insan Madani

[6] Trianto. (2009). Mendesain Model Pembelajaran Inovatif Progresif: Konsep, Landasan, dan Implementasinya pada Kurikulum Tingkat satuan Pendidikan. [Designing a progressive innovative learning model: concept, foundation, and implementation in the education unit level curriculum]. Jakarta: Kencana

[7] Herlina, M. (2017). The Use of Reciprocal Strategy in Teaching Reading Comprehension. Proceedings of the Fifth International Seminar on English Language and Teaching (ISELT-5), (5), 105-112. P-ISSN 2580-1287 E-ISSN 25976346

[8] Al-Makhzoomi, K. (2012). The Effect of Reciprocal Teaching Procedure (RTP) on enhancing EFL students' Reading Comprehension Behavior in a University Setting. International Journal of Humanities and Social Science, 2(5), 279-290.

[9] Ahmadi, M.R., Ismail, H.N., \& Abdullah, M.K.K. (2013). Goals of Reciprocal Teaching Strategy Instruction.The International Journal of LanguageLearning and Applied Linguistics World, 2(1), 18-27. 